\title{
FOUNDING FAMILY OWNERSHIP AND FIRM PERFORMANCE: EMPIRICAL EVIDENCE FROM CONSUMER GOODS INDUSTRY IN INDONESIA
}

\author{
Margareta Bambang ${ }^{1}$ \\ BINUS Business School \\ Marko S. Hermawan ${ }^{2}$ \\ BINUS Business School
}

\begin{abstract}
This research investigates the significant influence of family ownership on firm performance in order to provide information to decision makers and other interested parties. The analysis includes comparisons between family and non-family firm performance in Indonesia. The samples are taken from 31 consumer goods companies, listed on the Indonesian Stock Exchange, ranging from 2005 to 2009. The results show that non-family firms perform better than family firms and no significant influence between family ownership and firms' profitability. On the other hand, family ownership has negative contribution to firm market valuation. The study suggests that family firms have lower financial performance than that of non-family. Family members within the top position have major control rights and contribute a negative influence to firm performance. The evidence raises concerns about possible profit manipulation and weak governance law in Indonesia, and as a result there is an expropriation of wealth to the majority and family related shareholders.
\end{abstract}

Keywords: ownership structure, family firms, firm performance, Indonesia.

\footnotetext{
${ }^{1}$ Alumni of BINUS Business School

${ }^{2}$ Faculty of BINUS Business School (marko@binus.edu)
}

112) B. Margareta \& Marko, S.H /Journal of Applied Finance and Accounting,4(2),112-131 


\section{INTRODUCTION}

Family-controlled firm is a common and unique business organization and often raise particular questions concerning succession and governance. The common issue raised is relationships and succession between management, board members and family members (Kenyon-Rouvinez, 2004). Recent studies regarding ownership structure stated that a large number of listed companies in do not show a wide dispersed ownership structure. These types of companies generally have one or more dominant shareholders that can be classified as families, states, foreigners, or financial company (Isakov \& Weisskopf, 2009). Some developed country such as United States found that family businesses can contribute 62\% of Gross Domestic Product (Shanker \& Astrachan, 1996), while in several European countries like France, Belgium, Germany, Italy, Sweden, Spain, Portugal, the proportion of family business is very large (Astrachan \& Shanker, 2003). In the case of Indonesia, family business contributes $82 \%$ of Gross Domestic Product (GDP) in which $90 \%$ of the listed companies are family firms (Susanto, 2000).

There are unique challenges that family business groups face, mainly concern with family dynamics and ownership. Negative perception often juxtaposed this term, since family business is considered as ineffective, collusive and unprofessional. Family firms are assumed to be more vulnerable between the company's interests with the interests of the family. Although not all positions in family firm are filled by family members at the top level, the company also employs other professional staffs. The majority voting rights owned by family members provide the rights to reject the minorities. In addition, according to Barclay and Holderness (1989) the high ownership shares by the family will reduce the ability to get investors from external parties and will reduce the market value of the company.

Family firms are characterized by the founding family's concentrated ownership and the founding family members' involvement in firms' management either as top executives or as directors. Family ownership has both costs and benefits, but the positive effects of family ownership overcome the negative effects to the firm value.

B. Margareta \& Marko, S.H /Journal of Applied Finance and Accounting,4(2),112-131 (113 
The purpose of this study is to investigate company's family ownerships and the impact to the company's performance (Chu, 2009). Furthermore, this paper will observe other non-family ownership factors such as government intervention, and other financial institution and foreign investments.

Business and family are two aspects that are not easily combined. Although there are many negative outlooks about the existence of a family business, previous findings found family firms generate better performance than those of non-family. The main purpose of this study is to describe the characteristic of the family business in Indonesia and to compare between the family and non-family company's performance. To support this purpose, the numbers of questions are raised: Is non-family business performance stronger than family business performance? And is there any significant influence of family business ownership to firm performance?

The rest of the article is described as follows. The first section focusses on the theoretical and hypothesis development, the second section outlines the methodology underlying the research. The third section presents the data collection, the fourth section describes the empirical analysis and discussion. The last section concludes the findings with certain limitation.

\section{THEORETICAL AND HYPOTHESIS DEVELOPMENT}

Ownership structure is an important factor to determine the firm value. Ownership structure refers to the size of their holdings and the identities of a firm's equity holders. Boubakri, Cosset, and Guedhami (2005) divides the shareholding patterns into two major dimensions; the size of ownership (majority and non-majority), and the identity of ownership (family and non-family ownership). Aspects such as number of stockholders, concentration of shares on minority shareholders, and the non-family stockholders, can affect succession planning and family involvement in the firm (Daily \& Dollinger, 1992).

The problem raises when a firm ownership is concentrated, in which the typical case occurred in Western Europe and the most of Asia. 
This type of company are different when firm ownership is dispersed, as is typically for firms in US, Japan, and UK. Conflicts of interest between controlling shareholders and minority shareholder becomes a problem when the ownership is concentrated at one owner that has effective control of the firm, However, when ownership is diffused, conflict of interest between managers and shareholders are a central problem (Jensen \& Meckling, 1976).

The first generation of a family firm tends to concentrate into one owner than that after several generations. During this phase, strategies may be designed and carried out according to the decision-making processes that centralize on the firm's leader. On the other hand, family businesses with dispersed capital are more difficult to develop similar kind of leadership, and long-term strategic orientation might be designed through negotiation processes and agreements between family members and shareholders (Casillas, Acedo, \& Moreno, 2007). Leach and Bogod (1999) argue that family business may differ in certain ways compared to the non-family ones. One of them is characteristic, which is shaped by its own set of typical personalities, concerns, objectives, and relationship. The characteristic of family business involves high involvement management such as decision making and policy business. The owner, which is one of the family members, influences every step of the progress and sometimes involves the heirs in business as soon as they start to work.

Several studies support the development of the hypotheses which investigate relationships between concentrated ownership structure and firm value. In contrast, many studies failed to confirm a positive association between firm performance and ownership concentration. Arifin (2003) investigates listed firms in Indonesia and found that family-controlled firms have fewer agency problems than the publicly-controlled firms or firms without controlling shareholders. He suggests that the agency problems in family-owned firms are fewer as a cause of less conflict between the principal and agent. On the other hand, if there are minority interests in family-owned firms, there will be conflict of interests between majority (family) and minority ownership.

Anderson and Reeb (2003) conducted a study on the relationship between family ownership structure to corporate performance using

B. Margareta \& Marko, S.H /Journal of Applied Finance and Accounting,4(2),112-131 (115 
panel data from companies in the S \& P 500 index. They found that family firms have better performance compared to other companies, mainly in companies where the founder of the company is still actively become CEO of the company (founder effect). Another study conducted by Morck, Stangeland, and Yeung (1998), found no relationship between corporate performance (as measured by Tobin's Q) with the percentage of management ownership. Along with rising interest from 0 to $5 \%$, the company's performance also increased. In the range from 5\% ownership further to 25\%, decreased the company's performance. When the concentration of ownership is above $25 \%$, the company's performance rises slowly. The percentage of management ownership between 0 to $5 \%$ formed alignment-interest effect that can increase company performance. While the percentage of ownership between $5 \%$ to $25 \%$ shows the entrenchment effect which occurs from management ownership that have a bad effect on performance. Ownership percentage above 25\% could weaken the entrenchment effects occurred.

Claessens, Djankov, Fan, and Lang (2002) examined the same topic with a sample of 1,301 public companies from 8 countries in East Asia, including Indonesia. In their research, Indonesia is the only country that shows the effects of entrenchment and alignment with the same level of significance strong. The sample data of companies in Indonesia shows a positive relationship between ownership with the valuation. However, this sample also shows the relationship negative magnitude of the differences between ownership and control with a valuation on $1 \%$ significance level.

Villalonga and Amit (2006) examine how family ownership, control and management within the company affect the value of the companies. They examined the companies listed in Fortune-500 on period 1994-2000, and find that ownership by the family increases value firms if the pioneers or inventors to be a CEO or a chairman with a hired CEO. However, when generation his successor as CEO, the value of the company declined. Their findings indicates that the owner-management conflicts in non-family firms spend more than the cost of the conflict between family and holder non-family shares in companies with pioneer or inventor became CEO. But nevertheless, conflicts between family shareholders non-family shares in the company where future generations into CEOs spend more than the 
cost of the conflict between the owner-management in non-family firms.

Based on the above literature, this paper attempts to develop two hypotheses.

$H_{1}$ : Non-family business performance is stronger than family business performance.

$\mathrm{H}_{2}$ : There is significant influence of family concentrated ownership to firm performance.

\section{RESEARCH METHOD AND DATA COLLECTION}

In order to answer the above, a model is prepared based on the supporting literatures. The variables included in the models contribute the determinant to which family and non-family enterprises influence company's performances. As indicated in the literature, ownerships variables represent the main factors alongside controlling variables.

\section{Dependent Variables}

The application of the models employ two dependent variables to measure company performance, namely ROA and Tobin's Q. ROA is used to measure accounting performance of the company, while Tobin's Q will be used to measure market performance of the company. The use of market value than accounting-based measures of profitability has become extensive in empirical analyses of firm profitability (Hirsch \& Seaks, 1993). Tobin's Q is a forwardlooking measure that reflects the market's valuation of firm's assets relative to book value and sometimes used as a proxy for a firm's future growth opportunities (King \& Segal, 2008). The advantage of using Tobin's $\mathrm{q}$ is that the difficult problem of estimating either rates of return or marginal costs can be avoided (Lindenberg \& Ross, 1981). This study uses Tobin's $Q$ ratio as the ratio of total liabilities plus the market value of equity divided by the book value of total assets. The market value of equity is calculated by multiplying the number of outstanding shares of a company with its current market price. Due to the changing nature of these values, the author uses the closing stock prices on the last trading 
day of years 2005-2009. A company's market value of equity is therefore always changing as these two input variables change. When the stock price of a company goes up consistently, overall market value of equity will goes up as well. The market value of equity of a company enables to analyse the degree to which the stock is available at expensive, cheap or fair valuations. A proxy of Tobin's Q also used by Morck et al. (1998), Martínez, Stöhr, and Quiroga (2007), Andres (2008), Miller (2007), Villalonga \& Amit (2006), Adams, Almeida, and Ferreira (2009), Anderson and Reeb (2003), Khanna and Palepu (2000).

The other dependent variable to be employed is Return on Assets (ROA). ROA measures a company's profits compared to its entire investment. ROA is a backward-looking measure that reflects accounting rules, and it is viewed as a measure of profitability or productivity (King \& Segal, 2008). ROA as dependent variable also used in similar studies by Villalonga and Amit (2006), Isakov and Weisskopf (2009), Adams et al. (2009), Andres (2008), Chu (2009), Martínez et al. (2007).

\section{Independent Variables}

First independent variable symbolized by Owner1 is a numerical measure, which indicates the percentage of equity owned by family founder or descendants, as an individual or organization. This number is derived from Laporan Kepemilikan Saham yearly and BEI Performance Summary for every company. This dummy variable also used by Chu (2009) in his study. Family Firm Dummy is a variable that classifying companies in the sample research into family firms and non-family firms. This variable will be worth 1 if a firm including in the category of family firms and will be 0 if included in category of non-family firms. Anderson and Reeb (2003), Andres (2008), Martinez(2007), Villalonga and Amit (2006), Miller (2007), Isakov and Weisskopf (2009) construct this dummy variables in their model to differentiate between family and nonfamily firms.

\section{Control Variables}

The influence of firm age on the survival and growth of firms has long been developed in previous literature. According to Daily and Dollinger (1992) studies, the age of family and non-family firms 
might be different because of different succession challenges. Firm Age is defined as the natural logarithm of company age since establishment of the company or the first year when the family founder take over, until the certain year (2005; 2009). This measurement is consistent with Villalonga and Amit (2006), Andres (2008), and Chu (2009).

According to Kole (1995), in the industrial organization literature, firm size reflects the existence of economies and diseconomies of scale and may form barriers to entry. Firm size can also influence the relationship between family ownership and firm performance. To avoid the extreme result value problem, firm size is controlled by using the natural logarithm of the five years average (2005-2009) firm’s total assets.

The debt-equity ratio or leverage, measures the proportion of funds provided by creditors and stockholders using to finance its assets. High leverage generally means that a company has been aggressively financed its economic growth by debt. Isakov and Weisskopf (2009), Adams et al. (2009), Andres (2008) employ debt to equity ratio into their research model.

The above variables formulate the two proposed models, as follows:

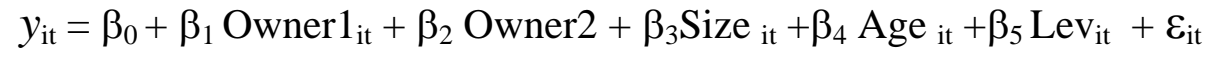

where,

$y$ : firm performance, measured by Tobin's Q (market performance) and ROA (accounting performance)

Owner1 : percentage of equity owned by family members

Owner2 : dummy variable, which combines the existence of family equity and the presence of family members on the top position in company (family=1; non-family=0)

Size : natural logarithm of firm's total assets

Age : natural logarithm since of the number years since the establishment of the firm

Lev : ratio of total debt over total shareholder's equity

$\varepsilon \quad:$ an error term 


\section{Data Collection and Analysis}

As for data collection, the sample of this study will be divided into two groups: family firm and non-family firm. This study will use the criteria of a family company as used by Miller (2007) and Allouche, Amann, Jaussaud, and Kurashina (2008). The criterion consists of shares owned by at least $5 \%$ of certain families and less than $5 \%$. The family member can have a position on the Board of Directors or Board of Commissioners of the company. This is also in accordance to regulation by Indonesian stock exchange, in that the minimum limit ownership by family is $5 \%$. Thus, companies' classification between family firms and non-family firms can be easily conducted because of availability data in BEI. Based on this criterion, there are 19 family firms and 12 non-family firms in the consumer industry.

Samples in this study include consumer goods firms in Indonesian listed companies during 2005 until 2009. Two consumer goods firms have to be excluded from all testing due to incomplete financial reports for a certain year or companies are inactively traded for a certain year. The firms which can be used for this study is 31 firms from 33 total consumer goods firms. These data are collected through Indonesia Stock Exchange Database, Indonesia Capital Market Directory (ICMD), and from company's website. This research obtains secondary data which collect the annual report of Indonesia listed company that is provided freely. For further information to support the research process, the author also use IDX fact book, articles, journals, textbook, and magazine.

\section{FINDINGS AND DISCUSSIONS}

Prior to descriptive analysis, a normality test is conducted to determine whether the data samples are normally distribution or not. By using Kolmogorov-Smirnov test, the provided sample data is not normally distributed and thus Spearman non-parametric test will be used for correlation analysis, presented in table 1 below. 
Table 1. Spearman' Correlation and Multicollinearity

\begin{tabular}{|lccc|}
\hline Variables & ROA & Tobin's Q & VIF \\
\hline Size & $0.290^{* *}$ & $0.238^{* *}$ & 1.074 \\
Age & $0.515^{* *}$ & $0.396^{* *}$ & 1.092 \\
Leverage & $-0.255^{* *}$ & 0.084 & 1.012 \\
Owner 1 & -0.110 & $-0.367^{* *}$ & 1.650 \\
Owner 2 & $-0.235^{* *}$ & $-0.456^{* *}$ & 1.689 \\
\hline
\end{tabular}

Table 1 illustrates correlation and multicollinearity tests between dependent and independent variables. Based from the table, most independent variables have significant correlation with the two dependent variables (significant level of 0.01). Only two variables, namely Owner 1 has less significant correlation with ROA, and Leverage with Tobin's Q. Negative correlations occur between Tobin's Q and Owner2 (-0.456) and Tobin's Q and Owner1 (0.367). The result shows that the higher the family ownership in company, the lower the firm market performs., There is also negative correlation between ROA and leverage $(-0.255)$, in that the more debt financed by shareholder's equity, the lower the accounting profit generated from total assets.

Table 2 presents the descriptive statistics for family and non-family ownerships in consumer goods industry. The table shows the average size for all samples is 27.5131. The average value of size (natural log of total asset) in family firms is slightly higher than non-family firms $(27.5675>27.4270)$. In addition, the table shows various leverage mean (the proportion of total debt to total equity) for each of the groups. The full sample present a 1.5137 mean while the family firms' leverage average is 1.0844 and non-family firms of 2.5705. These results illustrate that family firms are presumed to have less debt than the non-family ones. The average of firm's age for full sample, family and non-family are 0.4112, 3.5096 and 3.6247 , respectfully. This indicates that the age of firms do not provide significant differences despite the family firms are relatively younger than those of non-family. In terms of firm's value measured by Tobin's Q and ROA, the description shows that family firms has smaller values than non-family firms. The average value of ROA in non-family firms (13.39\%) shows almost double than 
family firms (6.85\%). Market measures as indicated by Tobin's Q shows that non-family firms have significantly greater valuation compared to family firms (3.5491>1.3151).

In terms of ROA and Tobin's Q means, the description finds the non-family firms have better performance than those of family firms. Additionally, high ROA firms are more profitable than low ROA firm. Firms with high ROA can grow faster than low ROA firms without borrowing or selling additional shares to raise capital. The finding is different with Allouche et al. (2008) who found that family listed firms in Japan perform better than non-family firms in terms of their ROA, ROE and ROIC. Moreover, the finding contradicts with Anderson and Reeb (2003) and Martínez et al. (2007) which argue that family enterprises are superior than the nonfamily ones. In terms of leverage, the mean for full sample is 1.6596 while the leverage ratio for family and non-family are 1.0844 and 2.5705 respectively. The results show that the family ownership uses less debt, compared with the non-family ones. This finding is also with Anderson and Reeb (2003) and Ibrahim and Samad (2011).

Table 2. Descriptive Statistics

\begin{tabular}{|c|c|c|c|c|}
\hline Variables & $\begin{array}{r}\text { Full } \\
\text { (N= } \\
\text { Mean }\end{array}$ & $\begin{array}{l}\text { ample } \\
1.5 .5) \\
\text { Std Dev }\end{array}$ & $\begin{array}{c}\text { Family } \\
\text { (N=9.5) } \\
\text { Mean }\end{array}$ & $\begin{array}{c}\text { Non- } \\
\text { Familv } \\
\text { Mean }\end{array}$ \\
\hline Size & 27.5131 & 1.5137 & 27.5675 & 27.427 \\
\hline Leverage & 1.6596 & 9.9444 & 1.0844 & 2.5705 \\
\hline Age & 3.5542 & 0.4112 & 3.5096 & 3.6247 \\
\hline ROA & 0.0938 & 0.2109 & 0.0685 & 0.1339 \\
\hline Tobin's Q & 2.1798 & 4.2151 & 1.3151 & 3.5491 \\
\hline
\end{tabular}

Table 3 illustrates Panel A of ROA model. Based from the regression model, the adjusted $\mathrm{R}^{2}$ is $16.9 \%(0.169)$ which can be interpreted that this model enables to explain ROA by firm size, firm age, leverage, owner 1 , and owner 2 . 
From Table 4 it can be concluded that $13.7 \%$ Tobin's Q can be explained by firm size, firm age, leverage, owner 1, and owner2 by looking at adjusted R-squared value. Two possible reasons, either the model is affected by multicollinearity or the presence of supporting variables that are not used in this research.

Table 3. Panel A model - ROA

\begin{tabular}{|lccc|}
\hline \multicolumn{1}{|c}{ Variable } & Coefficient & $\begin{array}{c}\text { t- } \\
\text { statistics }\end{array}$ & $\begin{array}{r}\text { p- } \\
\text { value }\end{array}$ \\
\hline ROA & -0.784 & -2.688 & 0.008 \\
Size & 0.006 & 0.549 & 0.584 \\
Age & 0.209 & 5.315 & $0.000^{*}$ \\
Leverage & 0.000 & -0.133 & 0.894 \\
Owner1 & -0.015 & -0.232 & 0.817 \\
Owner2 & -0.036 & -0.885 & 0.377 \\
Adj R-Squared & 0.169 & & \\
F-Statistic & 7.261 & & \\
Prob (F- & 0.000 & & \\
Statistic) & & & \\
\hline
\end{tabular}

Table 4. Panel B model - Tobin's Q

\begin{tabular}{|lccc|}
\hline \multicolumn{1}{|r}{ Variable } & Coefficient & t-statistics & p-value \\
\hline Tobin’s Q & -10.887 & -1.833 & 0.069 \\
Size & 0.121 & 0.562 & 0.575 \\
Age & 3.072 & 3.831 & $0.000^{*}$ \\
Leverage & -0.011 & -.348 & 0.729 \\
Owner1 & 0.214 & 0.166 & 0.869 \\
Owner2 & -2.000 & -2.383 & $0.018^{*}$ \\
\hline
\end{tabular}

B. Margareta \& Marko, S.H /Journal of Applied Finance and Accounting,4(2),112-131 (123 


\begin{tabular}{|c|c|c|c|}
\hline Variable & Coefficient & t-statistics & p-value \\
\hline Adj R-Squared & 0.137 & & \\
\hline F-Statistic & 5.892 & & \\
\hline Prob (F-Statistic) & 0.000 & & \\
\hline
\end{tabular}

Leverage variable is negatively correlated with ROA and Tobin's $\mathrm{Q}$ but insignificant at p-value of 0.894 and 0.729 . This result contradicts with Friend and Lang (1988) who argues debt-financing decision might have a negative impact on firm performance. High debt financing may outweigh the return a company generates on the debt through investment and other business activities. Moreover, Other researchers examine the effect of leverage to firm profit and make the conclusion about significantly negative relationship between profitability and leverage (Achmad, Rusmin, Neilson, \& Tower, 2008).

The firm age variable in all samples of the study is 3.55 and is not statistically different between family and non-family ownership in this sample. Even though there is no significant difference in age between family and non-family, family firms are younger than nonfamily firms (3.51 versus 3.62) consistent with Villalonga and Amit (2006), Anderson and Reeb (2003), and Ibrahim and Samad (2011). Based on the two panel regression analyses, firm age as controlling variable generates significant contribution towards company's performance. The more mature or well established the company is, the better the performance of the company, measured from its accounting profit (ROA), or by using market valuation (Tobin's Q). A general assumption to this behaviour is that investors pressume to have positive perspective towards firms that enable to survive through economic fluctuation and market conditions.

The percentage of total equity owned by family members represented by owner1 variable prove not to contribute any significant influence to firm's performance, either distinguished by ROA or Tobin's Q models. A possible reason is due to incomplete information and bias data in getting the exact amount of family

124) B. Margareta \& Marko, S.H /Journal of Applied Finance and Accounting,4(2),112-131 
percentage ownerships. These results contradict with previous studies such as Jensen and Meckling (1976) and Boubakri et al. (2005) which suggest the concentration of family shareholders is significantly and positively related to firm performance.

The other variable, Owner 2 dummy variable to return on assets, is negatively insignificant to firm performance. This finding is inconsistent with Demsetz and Lehn (1985), results. On the other hand, this result consistent to several previous studies, which found that family control, is not related to firm performance (Himmelberg, Hubbard, \& Palia, 1999). Related to the Tobin's Q model, Owner2 variable is significantly influencing market firm performance with $p$-value of 0.018 ( $\mathrm{p}<0.005)$. Tobin's $\mathrm{Q}$ is measured by market value of equity over book value of assets. Market value of equity is calculated by multiplying the company's current stock price by its number of outstanding shares. A company's market value of equity is therefore always changing as these two input variables react. When the stock price of a company goes up consistently, overall market value of equity will goes up as well. Market value of equity of a company can help us analyze whether the stock is available at expensive, cheap or fair valuations. Specifically, this study found that 1\% change in family ownership is approximately associated with a decline of $200 \%$ in market value performance. This result means that family ownership concentration in firm give highly negative impact to its market valuation.

Recent research found various confiscation of minority shareholders across nations which are influenced by legal and regulatory institution (Dyck \& Zingales, 2004; La Porta, Lopez-deSilanes, \& Shleifer, 1999). Maury (2006) suggests benefits from family ownership fade with higher level of controls. Market valuation measured by Tobin's $\mathrm{Q}$ is predicted to become higher for firms with low family control, which can be interpreted as a sign to increase family opportunism and extraction of private benefits. Moreover, the profitability increases with family control level which shows that family management improves the efficiency of a company but that minority shareholders cannot really profit from it. 


\section{CONCLUSION}

Family firms' performance in Indonesia is concluded to have lower compared to non-family firms' performance by looking from its accounting profitability and market valuation. Therefore, this evidence further confirms that family firms tend to invest high shares with lower risks and lower returns. Furthermore, family ownerships concerns with family interest and the survival of the firms as family firms tend to be risk averse (Rahman, 2005). The other reasonable explanation is because family firms in Indonesia are not purely a family organization. Most family business in Indonesia is controlled under foundation or 'yayasan' which easily occurs various acts of corruption and collusion.

In regard to the role of concentrated family ownership and control in large firms in eight Asian countries, Jiang and Peng (2011) found that family ownership itself does not show significant effect on firm performance in some countries. On the contrary, this study found that in less-developed and more of corruption countries such as Indonesia tend to have more opportunities to expropriate minority shareholders.

There are several possible reasons with regard to negative impacts arising from the family ownership structures to firm performance. One of the problems is due to entrenchment issues surrounding the management in most of the family business in Indonesia. Entrenchment problem, which involve family owners and other members, may jeopardise corporate governance and control, and thus can detriment company performance. The domination of family control the company and the composition of the board of directors and management of family-controlled are some of the overt factors. According to Morck et al. (1998), the entrenchment issues are likely to increase whenever there is a dominant role of clan in recruiting directors and commissioners. In sum, the tendency to select their family members to manage in company which ownership is controlled by themselves (Demsetz \& Lehn, 1985).

Another possible factor is that there may be weak legal issues in Indonesia's minority shareholders. As a result, the majority of shareholders may acquire some of the rights of minority shareholders. 
Additionally, there is a possibility to increase their wealth to the majority and family shareholders while disadvantaging the minority and non-family shareholders (Achmad et al., 2008).

Some limitation encountered during the research process. This study does not differentiate types of family ownerships such as parents, sibling partnerships, which can be an important factors to determine the effect to company performance. Other limitation relating to application of purposive sample design in which the sample is limited to consumer goods industry. This sample selection may limit the generalisibility of the result which may not be applicable for other industries in Indonesia.

Several recommendations are purposed to further research. Firstly, one can extend the investigation to other emerging sampling design and expand time horizon. Further research can cover more sample periods to more than five years and the use all listed public firms from seven different industries as sample data in order to gain more relevance findings on the family business performance. This enables to generate better model in further research. Secondly, as this study only includes leverage, firm age, and firm size as the control variables, future research may incorporate debt in capital structure, industry classification, duality, growth into the research model (Villalonga and Amit,2006, Adams et al. (2009).

\section{REFERENCES}

Achmad, T., Rusmin, R., Neilson, J., \& Tower, G. (2008). The iniquitous influence of family ownership structures on corporate performance. The Journal of Global Business Issues, $3(1)$.

Adams, R., Almeida, H., \& Ferreira, D. (2009). Understanding the relationship between founder-CEOs and firm performance. Journal of empirical Finance, 16(1), 136-150.

Allouche, J., Amann, B., Jaussaud, J., \& Kurashina, T. (2008). The Impact of Family Control on the Performance and Financial Characteristics of Family Versus Nonfamily Businesses in 
Japan: A Matched-Pair Investigation. Family Business Review, 21(4), 315-329.

Anderson, R. C., \& Reeb, D. M. (2003). Founding-family ownership and firm performance: evidence from the S\&P 500. The Journal of Finance, 58(3), 1301-1327.

Andres, C. (2008). Large shareholders and firm performance-An empirical examination of founding-family ownership. Journal of Corporate Finance, 14(4), 431-445.

Arifin, Z. (2003). Masalah Agensi dan Mekanisme Kontrol pada Perusahaan dengan Struktur Kepemilikan Terkonsentrasi yang Dikontrol Keluarga: Bukti dari Perusahaan Publik di Indonesia. Unpublished Doctoral Dissertation, University of Indonesia, Jakarta.

Astrachan, J. H., \& Shanker, M. C. (2003). Family businesses' contribution to the US economy: A closer look. Family Business Review, 16(3), 211-219.

Barclay, M. J., \& Holderness, C. G. (1989). Private benefits from control of public corporations. Journal of financial Economics, 25(2), 371-395.

Boubakri, N., Cosset, J. C., \& Guedhami, O. (2005). Postprivatization corporate governance: The role of ownership structure and investor protection. Journal of financial Economics, 76(2), 369-399.

Casillas, J. C., Acedo, F. J., \& Moreno, A. M. (2007). International entrepreneurship in family businesses: Edward Elgar Publishing.

Chu, W. (2009). The influence of family ownership on SME performance: evidence from public firms in Taiwan. Small Business Economics, 33(3), 353-373.

Claessens, S., Djankov, S., Fan, J. P., \& Lang, L. H. (2002). Disentangling the incentive and entrenchment effects of large shareholdings. The Journal of Finance, 57(6), 2741-2771.

Daily, C. M., \& Dollinger, M. J. (1992). An empirical examination of ownership structure in family and professionally managed firms. Family Business Review, 5(2), 117-136. 
Demsetz, H., \& Lehn, K. (1985). The structure of corporate ownership: Causes and consequences. The Journal of Political Economy, 93(6), 1155-1177.

Demsetz, H., \& Villalonga, B. (2001). Ownership structure and corporate performance. Journal of Corporate Finance, 7(3), 209-233.

Dyck, A., \& Zingales, L. (2004). Private benefits of control: An international comparison. The Journal of Finance, 59(2), 537600 .

Friend, I., \& Lang, L. H. (1988). An Empirical Test of the Impact of Managerial Self-interest on Corporate Capital Structure. The Journal of Finance, 43(2), 271-281.

Himmelberg, C. P., Hubbard, R. G., \& Palia, D. (1999). Understanding the determinants of managerial ownership and the link between ownership and performance. Journal of financial Economics, 53(3), 353-384.

Hirsch, B. T., \& Seaks, T. G. (1993). Functional form in regression models of Tobin's q. The Review of Economics and Statistics, 381-385.

Ibrahim, H., \& Samad, F. A. (2011). Corporate Governance Mechanisms and Performance of Public-Listed FamilyOwnership in Malaysia. International Journal of Economics and Finance, 3(1), p105.

Isakov, D., \& Weisskopf, J.-P. (2009). Family ownership, multiple blockholders and firm performance. Working paper, University of Fribourg.

Jensen, M. C., \& Meckling, W. H. (1976). Theory of the firm: Managerial behavior, agency costs and ownership structure. Journal of financial Economics, 3(4), 305-360.

Jiang, Y., \& Peng, M. W. (2011). Are family ownership and control in large firms good, bad, or irrelevant? Asia Pacific Journal of Management, 28(1), 15-39.

Kenyon-Rouvinez, D. (2004). Family business: Key issues: Palgrave Macmillan. 
Khanna, T., \& Palepu, K. (2000). Is group affiliation profitable in emerging markets? An analysis of diversified Indian business groups. The Journal of Finance, 55(2), 867-891.

King, M. R., \& Segal, D. (2008). Market segmentation and equity valuation: Comparing Canada and the United States. Journal of International Financial Markets, Institutions and Money, 18(3), 245-258.

Kole, S. R. (1995). Measuring managerial equity ownership: a comparison of sources of ownership data. Journal of Corporate Finance, 1(3), 413-435.

La Porta, R., Lopez-de-Silanes, F., \& Shleifer, A. (1999). Corporate ownership around the world. The Journal of Finance, 54(2), 471-517.

Leach, P., \& Bogod, T. (1999). Guide to the family business: Kogan Page Publishers.

Lindenberg, E. B., \& Ross, S. A. (1981). Tobin's q ratio and industrial organization. Journal of Business, 1-32.

Martínez, J. I., Stöhr, B. S., \& Quiroga, B. F. (2007). Family ownership and firm performance: Evidence from public companies in Chile. Family Business Review, 20(2), 83-94.

Maury, B. (2006). Family ownership and firm performance: Empirical evidence from Western European corporations. Journal of Corporate Finance, 12(2), 321-341.

Miller, D., Le Breton-Miller, I., Lester, R. H., \& Cannella Jr, A. A. (2007). Are family firms really superior performers? Journal of Corporate Finance, 13(5), 829-858.

Morck, R. K., Stangeland, D. A., \& Yeung, B. (1998). Inherited wealth, corporate control and economic growth: The Canadian disease: National Bureau of Economic Research.

Rahman, A. R. (2005). Ownership of the Firm and Corporate Value. Working paper: Universiti Teknologi MARA. Selangor.

Shanker, M. C., \& Astrachan, J. H. (1996). Myths and realities: Family businesses' contribution to the US economy-A framework for assessing family business statistics. Family Business Review, 9(2), 107-123. 
Susanto, A., B. (2000). World class family business. Jakarta: Jakarta Consulting Group.

Villalonga, B., \& Amit, R. (2006). How do family ownership, control and management affect firm value? Journal of financial Economics, 80(2), 385-417. 